\title{
PENGARUH MODEL PEMBELAJARAN KOOPERATIF TIPE TEAM GAMES TOURNAMENT (TGT) TERHADAP HASIL BELAJAR PASSING CONTROL SEPAKBOLA
}

\author{
Muhammad Kartiko Kusuma Wardana ${ }^{1}$, I Putu Panca Adi ${ }^{2}$, I Gede Suwiwa ${ }^{3}$ \\ ${ }^{1,2,3}$ Program Studi Penjaskesrek, Fakultas Olahraga dan Kesehatan \\ Universitas Pendidikan Ganesha, Singaraja-Indonesia \\ email: md.kartiko99@gmail.com, drsputupancaadi@gmail.com, \\ suwiwagede@gmail.com
}

\begin{abstract}
Abstrak
Penelitian ini bertujuan untuk mengetahui pengaruh model pembelajaran kooperatif tipe TGT terhadap hasil belajar passing control sepakbola dalam PJOK. Penelitian ini merupakan eksperimen sungguhan (true experimental) dengan rancangan the posttest only control group design. Populasi penelitian adalah seluruh peserta didik kelas $\mathrm{X}$ SMA Negeri 2 Singaraja tahun pelajaran 2019/2020. Pengambilan sampel menggunakan simple random sampling dan didapat kelas X MIPA 2 sebagai kelompok eksperimen dan X IPS 1 sebagai kelompok kontrol. Perlakuan dilakukan sebanyak 3 kali perlakuan diluar posttest. Analisis data menggunakan uji-t dengan bantuan SPSS 16.0 for Windows. Signifikansi pada uji hipotesis diperoleh melalui uji parametrik (uji Independent Samples Test) adalah 0.001 yaitu $\mathrm{p}<0,05$. Disimpulkan bahwa model pembelajaran kooperatif tipe TGT berpengaruh signifikan terhadap hasil belajar passing control sepakbola dalam PJOK di SMA Negeri 2 Singaraja. Disarankan kepada guru PJOK dapat menerapkan model pembelajaran kooperatif tipe (TGT) karena terbukti berpengaruh signifikan terhadap hasil belajar peserta didik.
\end{abstract}

Kata-kata kunci: kooperatif, TGT, hasil belajar, passing control, sepakbola

\begin{abstract}
This study aimed to determine the effect of the cooperative learning model of Team Games Tournament type on learning outcomes of football passing control in Physical Education, Sport, and Health (PJOK). The type of study was true experimental research with the post-test only control group design. The population of the study was all $X$ grade students of State Senior High School 2 Singaraja in the 2019/2020 academic period. The sampling used simple random sampling and selected as the research sample was class X MIPA 2 as the experimental group and X IPS 1 as the control group. The treatment was provided 3 times outside the post-test. The data analysis used t-test with the help of SPSS 16.0 for Windows. The significance of the hypothesis test was obtained through the parametric test (Independent Samples Test) of 0.001, with $p<0.05$. It can be concluded that the cooperative learning model of TGT type had a significant effect on the learning outcomes of football passing control in PJOK in State Senior High School 2 Singaraja. It can be concluded that cooperative learning model of TGT type had the significant effect on student learning outcomes.
\end{abstract}

Keywords: cooperative learning, TGT, learning outcomes, passing-control, football 


\section{PENDAHULUAN}

Pendidikan

merupakan

kebutuhan dalam kehidupan seeorang. Melalui pendidikan, generasi muda tidak hanya dapat belajar tentang pengetahuan melainkan juga mengembangkan sikap spiritual, sikap sosial, potensi, keterampilan, dan kreatifitas yang dimiliki. "Pendidikan merupakan kegiatan yang dilakukan secara sadar berupa pengajaran baik pikiran dan jasmani peserta didik yang berlangsung sepanjang hayat untuk meningkatkan kepribadiannya agar mendapat peran di lingkungan hidup secara tepat yang selaras dengan alam dan masyarakat" (Purwanto 2014:24).

Pendidikan tak terlepas dari kurikulum yang merupakan pedoman dalam penyelenggaraan kegiatan pembelajaran mengenai isi dan bahan pelajaran. Menurut Winecoff (dalam Dimyati dan Mudjiono, 2006:266) mendefinisikan kurikulum sebagai rencana yang dikembangkan untuk mendukung proses belajar/mengajar didalam sekolah, akademi/universitas. Kurikulum yang berlaku pada sistem pendidikan nasional sekarang menggunakan kurikulum 2013 (K13) karena K13 merupakan kurikulum yang dikembangkan untuk meningkatkan dan menyeimbangkan kemampuan soft skills dan hard skills yang berupa sikap (Afektif), keterampilan (Kognitif), dan pengetahuan (Psikomotor) dalam berbagai mata pelajaran, salah satunya yaitu PJOK.

PJOK di Indonesia diharapkan mampu berkembang, baik aspek kognitif, afektif dan psikomotor. Sarana dan prasarana juga sangat mendukung untuk mewujudkan hasil dari PJOK itu sendiri. PJOK juga bertujuan ikut membantu meningkatkan kualitas manusia yang menekankan pada pembinaan perilaku hidup sehat, melalui prinsip pendidikan jasmani.
Pembelajaran PJOK merupakan media untuk mendorong perkembangan keterampilan motorik, kemampuan fisik, pengetahuan, penalaran, penghayatan nilai, dan pembiasaan pola hidup sehat yang bermuara untuk merangsang pertumbuhan serta perkembangan yang seimbang (Tama, dkk. 2019:36)

Peran guru dalam proses pembelajaran sangatlah penting, karena berhasil tidaknya suatu pembelajaran tergantung bagaimana guru tersebut mampu mengelola komponenkomponen yang mendukung dalam suatu proses pembelajaran (siswa, sumber, media, dan lingkungan belajar). Kualitas proses pembelajaran menentukan hasil belajar, oleh karena itu guru harus mampu merancang proses pembelajaran dengan baik. Faktor guru sangat mempengaruhi kualitas pembelajaran karena guru merupakan alat pendukung pembelajaran yang bertugas mempersiapkan dan mengelola pembelajaran. Selain itu guru sebagai pendidik juga harus mampu menciptakan suasana belajar yang menarik dan kreatif untuk para peserta didik dengan memanfaatkan fasilitas yang ada disekolah untuk mewujudkan kondisi belajar yang diinginkan

Masalah tersebut dilihat berdasarkan hasil observasi pada peserta didik kelas $\mathrm{X}$ dimana peserta didik dalam pembelajaran PJOK khususnya pada materi passing-control sepakbola yang memiliki nilai rendah yaitu hanya 97 orang (32\%) dan yang belum mencapai nilai KKM sebanyak 204 orang $(68 \%)$ dari Kriteria Ketuntasan Minimal (KKM) yaitu 70. Masalah tersebut dilihat dari kemampuan peserta didik saat melakukan gerakan passingcontrol sepakbola dimana mereka masih kesusahan dalam menemukan gerakan yang efektif dan benar. 
Berdasarkan hasil observasi mengenai teknik dasar passing-control sepakbola menggunakan kaki bagian dalam, didapatkan permasalahan yang menyebabkan rendahnya aktivitas dan hasil belajar peserta didik kurang melakukan kerjasama dengan teman, maka peneliti mencoba memberi alternatif pemecahan dari permasalahan pembelajaran yang ada. yaitu dengan menggunakan penerapan model pembelajaran kooperatif tipe TGT dalam pembelajaran PJOK materi teknik dasar passing-control sepakbola. Aktivitas belajar dengan permainan yang dirancang dalam pembelajaran kooperatif tipe TGT memungkinkan peserta didik diajak untuk lebih menikmati pembelajaran, lebih santai namun tetap bertanggung jawab dalam persaingan sehat dan sosialisasi antar sesama peserta didik yang tinggi. Menurut Nugroho dan Rachman (2011:72) kelebihan model pembelajaran kooperatif tipe TGT: (1) Meningkatkan pencurahan waktu untuk tugas gerak, (2) Mengedepankan penerimaan terhadap perbedaan individu, (3) Dengan waktu yang sedikit dapat menguasai materi secara mendalam, (4) Proses belajar mengajar berlangsung dengan keaktifan dari peserta didik, (5) Mendidik peserta didik untuk berlatih bersosialisasi dengan orang lain, (6) Motivasi belajar lebih tinggi, (7) Hasil belajar lebih baik, (8) Meningkatkan kerjasama, dan persaingan sehat.

Model pembelajaran kooperatif tipe TGT ini sudah pernah diteliti sebelumnya dan terbukti meningkatkan hasil belajar peserta didik dari peneliti terdahulu tentang penerapan model pembelajaran kooperatif tipe TGT. (1) Sukmawibawa (2016) Model pembelajaran kooperatif tipe TGT berbantuan video pembelajaran berpengaruh signifikan terhadap hasil belajar dribbling bola basket. dengan hasil Uji t diperoleh nilai $\mathrm{t}=6.542$ dan nilai signifikansinya $=0.001$. (2) Pertiwi (2017) Berdasarkan angka ratarata terlihat bahwa rata-rata peningkatan hasil belajar pada kelompok eksperimen 81,37 lebih besar daripada kelompok control 74,53. Dapat disimpulkan bahwa hasil belajar pada siswa yang dibelajarkan menggunakan model pembelajaran kooperatif tipe TGT lebih tinggi daripada siswa yang dibelajarkan menggunakan model pembelajaran konvensional. (3) Hijria (2017) Penerapan model pembelajaran kooperatif tipe TGT berpengaruh signifikan terhdap peningkatan hasil belajar teknikdasar passing bola basket pada siswa kelas XI SMK TI Bali Global singaraja tahun pelajaran 2016/2017 dengan rata-rata nilai posttest pada kelompok eksperimen adalah 79,66 sedangkan kelompok control 64,37. (4) Iswardhani (2019) Hasil dari uji wilcoxon yaitu Asymp.Sig. (2-tailed) 0,000 lebih kecil dari < 0,05 maka hipotesis diterima yaitu terdapat pengaruh model pembelajaran kooperatif tipe Teams Games Tournaments (TGT) pada kelas eksperimen.

Berdasarkan permasalahan di atas maka peneliti mengangkat penelitian tentang Pengaruh Model Pembelajaran Kooperatif Tipe TGT terhadap Hasil Belajar Bola Besar (Passing-Control Sepakbola) Dalam PJOK pada Peserta Didik Kelas X SMA Negeri 2 Singaraja.

\section{METODE}

Jenis penelitian yang digunakan dalam penelitian ini adalah eksperimen sungguhan (true experimental). Penelitian ini dilaksanakan di lapangan SMA Negeri 2 Singaraja dan dalam penelitian ini adalah seluruh kelas $\mathrm{X}$ yang terdapat di SMA Negeri 2 
Singaraja tahun pelajaran 2019/2020.Rancangan pada penelitian ini adalah rancangan the post test only control group design.

Jumlah populasi yang peneliti gunakan yaitu seluruh kelas $\mathrm{X}$ yang terdapat di SMA Negeri 2 Singaraja, dengan jumlah sebanyak 301 peserta didik dan terbagi menjadi 8 kelas. Sampel penelitian ditentukan dengan cara sampling acak sederhana (simple random sampling). Dimana peneliti mengambil sampel dengan melakukan lotre terhadap semua populasi. Pengambilan sampel dalam penelitian ini dengan cara random, peneliti hanya mengacak kelas yang terdapat di sekolah di SMA Negeri 2 Singaraja, oleh karena itu terpilih Kelas X IPS 1 berjumlah 38 orang dan X MIPA 2 berjumlah 38 orang sebagai sampel, sehingga keseluruhan jumlah sampel penelitian adalah 76 orang. Dua kelas yang ada diundi untuk menetapkan kelas yang menjadi kelas eksperimen dan kelas kontrol.

Pada penelitian ini data yang diperoleh adalah berdasarkan hasil penilaian asesmen teknik dasar passing control kaki bagian dalam sepak bola yang diisi oleh peneliti dan diawasi oleh 2 orang evaluator dari guru PJOK SMA Negeri 2 Singaraja. Prosedur pengumpulan data dilakukan dengan memberikan pretest sebelum perlakuan dan posttest setelah perlakuan. Tes yang diberikan pada kelompok eksperimen dan kelompok kontrol adalah tes yang sama. Instrumen yang digunakan adalah asesmen teknik dasar passing control kaki bagian dalam sepak bola. Asesmen adalah proses pengumpulan informasi atau proses pengumpulan data yang biasa memberikan gambaran perkembangan belajar siswa. Dalam pengujian instrumen penelitian ini dilakukan oleh pembimbing selaku ahli agar penelitian terkontrol dengan baik.
Pada penelitian ini hanya dikerjakan validitas isi dengan cara uji ahli.

Sebelum dilakukan pengujian untuk mendapatkan simpulan, data yang diperoleh perlu diuji normalitas dan homogenitasnya. Data yang diuji adalah data posttest. Analisis data pada penelitian ini menggunakan program SPSS 16.0 for Windows. Uji normalitas digunakan untuk menentukan data dalam kelompok sampel berdistribusi normal atau tidak. Apabila data berdistribusi normal, maka uji hipotesis dapat dilakukan. Pengujian normalitas sebaran data dengan menerapkan teknik Kolmogorov-Smirnov dengan taraf signifikansi 0,05. Uji KolmogorovSmirnov dapat digunakan. Uji homogenitas dilakukan untuk memperlihatkan bahwa data pemahaman hasil belajar siswa yang belajar dengan model pembelajaran kooperatif tipe TGT dan model pembelajaran langsung memiliki varian yang sama atau tidak. Uji homogenitas varian antara kelompok belajar juga digunakan untuk memastikan bahwa perbedaan yang terjadi pada uji hipotesis memang benar akibat adanya perbedaan dalam kelompok. Uji homogenitas varian antar kelompok menggunakan Levene's Test of Equality of Error Variance. Uji t dua sampel independent pada prinsipnya membandingkan rata - rata dari dua grup yang tidak berhubungan satu dengan yang lain, dengan tujuan apakah kedua grup tersebut mempunyai ratarata yang sama. Jika dari hasil uji normalitas dan homogenitas varians, diketahui bahwa data berdistribusi normal dan variansnya homogen maka untuk menguji hipotesisnya digunakan Independent Sample T-test dengan taraf signifikansi $5 \%$. 
HASIL DAN PEMBAHASAN

\section{Hasil Penelitian}

Penelitian ini adalah penelitian yang dilakukan pada dua kelompok. Dalam penelitian ini kelompok eksperimen diberikan perlakuan berupa model pembelajaran kooperatif tipe TGT dan pada kelompok kontrol diberikan perlakuan berupa model pembelajaran langsung. Pengambilan data pada kelompok eksperimen dan kontrol dilaksanakan pada tanggal 5 Februari sampai dengan 6 Maret 2020 untuk perlakuan dan 13 Maret 2020 (posttest).

Tabel 1. Data Hasil Belajar Teknik Dasar Passing Control Kaki Bagian Dalam Sepak Bola

\begin{tabular}{lccc}
\hline \multicolumn{4}{c}{ Descriptive Statistics } \\
\multicolumn{1}{c}{ Variabel } & $\begin{array}{c}\text { Banyak } \\
\text { Siswa }\end{array}$ & $\begin{array}{c}\text { Rata- } \\
\text { rata }\end{array}$ & $\begin{array}{c}\text { Std. } \\
\text { Deviation }\end{array}$ \\
\hline $\begin{array}{l}\text { Kelas kelompok } \\
\text { eksperimen }\end{array}$ & 38 & 81.17 & 3.523 \\
Kelas kelompok kontrol & 38 & 71.17 & 3.509 \\
\hline
\end{tabular}

Berdasarkan Tabel 1 subyek pada kelompok eksperimen sebanyak 38 orang, begitu pula subyek pada kelompok kontrol sebanyak 38 orang. Analisis statistik deskriptif data posttest kelompok eksperimen menunjukkan mean (rata-rata) hasil belajar teknik dasar passing-control bola dalam permainan sepak bola sebesar 81,17 dengan standar deviasi sebesar 3,523. Sedangkan, pada kelompok kontrol menunjukkan mean (rata-rata) hasil belajar teknik dasar menggiring bola dalam permainan sepak bola sebesar 71,17 dengan standar deviasi sebesar 3,509. Terlihat bahwa rata-rata hasil belajar teknik dasar passing-control
Pemberian perlakuan untuk kelompok ekperimen dilaksanakan pada Rabu 5 Februari, Rabu 12 Februari, dan Rabu 4 Maret 2020, sedangkan untuk kelompok kontrol dilakukan pada Jum `at 7 Februari, Jum `at 14 Februari, dan Jum`at 6 Maret 2020. Kegiatan penelitian dilakukan di lapangan sekolah SMA Negeri 2 Singaraja. Data yang dianalisis menggunakan SPSS 16.0 for Windows. Berikut data nilai kedua kelas tersebut pada tabel 1 . bola dalam permainan sepakbola kelompok eksperimen lebih tinggi daripada kelompok kontrol.

Pengujian normalitas sebaran data dilakukan untuk meyakinkan bahwa subjek penelitian berdistribusi normal. Untuk mengetahui normalitas sebaran data digunakan rumus Kolmogorov-Smirnov pada signifikansi 0,05 . Jika $p>0,05$ data berdistribusi normal, sebaliknya jika $p<0,05$ data tidak berdistribusi normal. Berdasarkan analisis yang telah dilakukan dengan menggunakan SPSS 16.00 for Windows didapatkan hasil seperti pada tabel 2 berikut. 
Tabel 2. Hasil Uji Normalitas Sebaran Data

\begin{tabular}{llrr}
\hline \multicolumn{4}{c}{ One-Sample Kolmogorov-Smirnov Test } \\
& & 38 & eksperimen \\
\hline $\mathrm{N}$ & Mean & 81.1697 & 71.1671 \\
Normal & Std. & 3.52264 & 3.50903 \\
Parameters ${ }^{\text {a,b }}$ & Deviation & & 38 \\
& Absolute & .175 & .135 \\
Most Extreme & Positive & .130 & .135 \\
Differences & Negative & -.175 & -.128 \\
Kolmogorov-Smirnov Z & 1.077 & .833 \\
Asymp. Sig. (2-tailed) & .197 & .491 \\
\hline a. Test distribution is Normal. & \multicolumn{3}{c}{} \\
b. Calculated from data.
\end{tabular}

Berdasarkan tabel 2 di atas, terlihat bahwa untuk semua variabel signifikansi pada uji KolmogorovSmirnov lebih besar dari 0,05 dengan rincian signifikansi kelompok eksperimen 0,197 dan signifikansi kelompok kontrol 0,491. Dengan demikian maka semua sebaran data berdistribusi normal Dengan demikian maka semua sebaran data berdistribusi normal.

Uji homogenitas varian dilakukan dengan pengelompokan berdasarkan model pembelajaran, yaitu model pembelajaran kooperatif tipe TGT dengan model pembelajaran konvensional. Uji homogenitas varians antar kelompok dilakukan dengan bantuan SPSS 16.00 for Windows dengan menggunakan Levene's Test Of Equality Error Variance dengan kriteria pengujian yang digunakan adalah terima $H_{o}$ jika nilai $p>0,05$ dimana data memiliki varians yang sama apabila angka signifikansi yang dihasilkan lebih dari 0,05. Rangkuman hasil perhitungan homogenitas dapat dilihat pada tabel 3 berikut.

Tabel 3. Hasil Uji Homogenitas Varians Data

\begin{tabular}{rrrr}
\hline \multicolumn{4}{c}{ Test of Homogeneity of Variances } \\
\hline Levene Statistic & df1 & df2 & Sig. \\
1.495 & 5 & 29 & .222 \\
\hline
\end{tabular}

Berdasarkan tabel 3, hasil uji Levene's Test of Equality of Error Variances $^{a}$ menunjukkan bahwa untuk hasil belajar materi teknik dasar passing-control kaki bagian dalam sepak bola diperoleh nilai signifikansi sebesar 0.222 . Taraf signifikansi yang ditetapkan adalah 0,05, maka dapat disimpulkan bahwa variansi pada setiap kelompok adalah sama (homogen).
Hipotesis penelitian yang telah dikemukakan dalam kajian teori menyatakan bahwa terdapat perbedaan hasil belajar materi teknik dasar passing control kaki bagian dalam sepak bola pada siswa yang dibelajarkan menggunakan model pembelajaran kooperatif tipe TGT dengan peserta didik yang dibelajarkan menggunakan model pembelajaran konvensional. Pengujian hipotesis menggunakan uji $\mathrm{t}$ 
dengan bantuan SPSS 16.00 for Windows dengan menggunakan independent samples $t$ test. Hasil analisis dengan uji $\mathrm{t}$ dapat dilihat pada tabel 4 berikut ini.

Tabel 4 Hasil Analisis Uji-t

One-Sample Test

\begin{tabular}{|c|c|c|c|c|c|c|}
\hline & \multicolumn{6}{|c|}{ Test Value $=0$} \\
\hline & \multirow[t]{2}{*}{$\mathrm{T}$} & \multirow[t]{2}{*}{ df } & \multirow[t]{2}{*}{$\begin{array}{l}\text { Sig. }(2- \\
\text { tailed) }\end{array}$} & \multirow[t]{2}{*}{$\begin{array}{c}\text { Mean } \\
\text { Difference }\end{array}$} & \multicolumn{2}{|c|}{$\begin{array}{l}95 \% \text { Confidence } \\
\text { Interval of the } \\
\text { Difference }\end{array}$} \\
\hline & & & & & Lower & Upper \\
\hline kontrol & 125.021 & 37 & .000 & 71.16711 & 70.0137 & 72.3205 \\
\hline eksperimen & 142.042 & 37 & .000 & 81.16974 & 80.0119 & 82.3276 \\
\hline
\end{tabular}

Berdasarkan tabel 4 diatas dapat
dilihat bahwa diperoleh nilai signifikansi 0,000 , maka $p<0,05$. Hasil ini dijadikan dasar dalam mengambil keputusan. Adapun keputusan yang diambil adalah tolak $H_{o}$ dan terima $H_{a}$. Hasil ini menyatakan bahwa terdapat perbedaan hasil belajar materi teknik dasar passing-control kaki bagian dalam sepak bola antara peserta didik yang menggunakan model pembelajaran kooperatif tipe TGT dengan peserta didik yang menggunakan model pembelajaran langsung. Sehingga model pembelajaran kooperatif tipe TGT berpengaruh signifikan terhadap hasil belajar PJOK materi teknik dasar passing control sepakbola pada peserta didik kelas X SMA Negeri 2 Singaraja

Dalam pelaksanaannya, ditemui beberapa kendala pada saat pembelajaran di kelompok eksperimen maupun di kelompok kontrol. Kendalakendala tersebut diantaranya yaitu: (a) terbatasnya waktu dalam menerapkan model pembelajaran kooperatif tipe TGT, (b) Banyak peserta didik yang pasif dalam mengikuti pelajaran karena kurangnya motivasi belajar.

Dari kendala-kendala yang dihadapi tersebut maka yang dilakukan peneliti untuk memecahkannya sehingga penelitian yang dilakukan dapat berjalan dengan lancar diantaranya yaitu: (a) meningkatan pencurahan waktu untuk tugas gerak serta membimbing peserta didik untuk saling membantu dan bekerja sama dalam setiap kelompok, (b) memberi motivasi dan penghargaan kepada individu kelompok terbaik dari materi yang dipelajari.

\section{SIMPULAN DAN SARAN Simpulan}

Berdasarkan hasil analisis data dan pembahasan dapat disimpulkan bahwa model pembelajaran kooperatif tipe team games tournament (TGT) berpengaruh signifikan terhadap hasil belajar bola besar (passing-control sepakbola) pada peserta didik kelas X SMA Negeri 2 Singaraja tahun pelajaran 2019/2020.

\section{Saran}

Berdasarkan hasil analis data dan pembahasan, maka dapat diajukan beberapa saran untuk proses pembelajaran dan penelitian lebih lanjut sebagai berikut.

1. Bagi guru PJOK, model pembelajaran kooperatif tipe TGT dijadikan salah satu alternatif 
pembelajaran yang dapat diterapkan di kelas.

2. Penelitian ini dilaksanakan pada pokok bahasan teknik dasar passingcontrol sepakbola di kelas X SMA Negeri 2 Singaraja, sehingga untuk memperoleh bukti-bukti yang lebih umum dari penerapan model pembelajaran kooperatif tipe TGT diharapkan peneliti lain untuk mencoba pada pokok bahasan lain untuk mengetahui pengaruh penerapan model pembelajaran pembelajaran kooperatif tipe TGT dalam pembelajaran PJOK secara lebih mendalam.

3. Penelitian ini hanya mengukur ada atau tidaknya pengaruh dari model pembelajaran kooperatif tipe TGT terhadap hasil belajar passingcontrol sepakbola tanpa meneliti lebih jauh arah pengaruh yang diberikan. Di waktu mendatang dapat dilakukan suatu penelitian untuk meneliti sejauh mana arah pengaruh yang diberikan oleh model pembelajaran kooperatif tipe TGT terhadap hasil belajar PJOK peserta didik.

\section{DAFTAR RUJUKAN}

Dimiyati dan Mudjiono. 2006. Belajar dan Pembelajaran. Jakarta: Rineka Cipta.

Hijria, Andini, dkk 2017. Pengaruh Model Pembelajaran Kooperatif Tipe Team Games Tournament (TGT) Terhadap Hasil Belajar Teknik Dasar Passing Bola Basket.

https://ejournal.undiksha.ac.id/in dex.php/JJP/article/view/11343. (diakses pada tanggal 29 Oktober 201922.20 WITA)

Ibrahim. 2017. Perpaduan Model Pembelajaran Aktif Konvensional (Ceramah) Dengan Cooperatif
(Make - A Match) Untuk Meningkatkan Hasil Belajar Pendidikan Kewarganegaraan. Jurnal Ilmu Pendidikan Sosial, Sains, dan Humaniora, Volume 3, Nomor 2 (hlm. 199-211). http://ejournal.uinsuska.ac.id/inde x.php/

suaraguru/article/view/3597.

(diakses pada tanggal 29 Oktober 201922.00 WITA)

Iswardhani dan Nurhasan. 2019. Pengaruh Model Pembelajaran Kooperatif tipe Team Games Tournament (TGT) Terhadap Hasil Belajar Dropshot Bulutangkis.

https://jurnalmahasiswa.unesa.ac. id/index.php/jurnalpendidikanjas mani/article/view/29441/26964 (diakses pada tanggal 10 April 2020 13.55 WITA)

Nugroho, Dian Riski dan Abdul Rachman. 2013. Penerapan Model Pembelajaran Kooperatif (Tipe Team Games Tournament) TGT terhadap Motivasi Siswa Mengikuti Pembelajaran Bola Voli di Kelas X SMAN 1 Panggul Kabupaten Trenggalek. https://jurnalmahasiswa.unesa.ac. id/index.php/jurnalpendidikanjas mani/article/view/2820/5733.

(diakses pada 4 Oktober 2019 22:49 WITA)

Pertiwi, Ni Kadek Ariani, dkk.2017. Pengaruh Penerapan Model Pembelajaran Kooperatif Tipt TGT Terhadap Hasil Belajar Teknik Dasar Passing Bola Basket.https://ejournal.undiksha.a c.id/index.php/JJP/article/view/11 222/7170 (diakses pada tanggal 10 April 2020 14.30 WITA) 
Purwanto, Nanang. 2014. Pengantar Pendidikan. Yogyakarta: Graha Ilmu

Rusman. 2012. Model-Model Pembelajaran. Jakarta: PT Raja Grafindo Persada

Ratumanan, Tanwey G. 2002. Belajar dan Pembelajaran. Surabaya: Unesa University Press.

Slavin, Robert.E. 2009. Cooperative Learning Ed Boston: Allyn and Bacon.

Sukmawibawa, I Gst Pt Octavianus, dkk. 2016. Pengaruh Model Pembelajaran Kooperatig Tipe TGT Berbantuan Video Pembelajaran Terhadap Hasil
Belajar Dribbling Bola Basket. https://ejournal.undiksha.ac.id/ind ex.php/JJP/article/view/864. (diakses pada tanggal 29 Oktober 201922.50 WITA)

Trianto. 2007. Model-model Pembelajaran Inovatif Berorientasi Konstruktivistik. Jakarta: Prestasi Pustaka Publisher

Tama, I Gede Surya, dkk. Pengaruh Model Pembelajaran Kooperatif Tipe Student Team Achievement Division (STAD) Terhadap Hasil Belajar Passing Sepakbola. https://ejournal.undiksha.ac.id/ind ex.php/PENJAKORA/article/view /17641 (diakses pada tanggal 19 Oktober 201921.40 WITA) 